\title{
PROFESIONALISME GURU DALAM UPAYA MENINGKATKAN MUTU PEMBELAJARAN
}

\author{
Oleh \\ Ketut Bali Sastrawan \\ Tenaga Pendidik pada STAHN Mpu Kuturan Singaraja
}

\begin{abstract}
Professionalism to the demands of each profession. Without exception the teaching profession who daily deal with the nation's future children with a variety of characteristics of each are not the same. Teachers are an important component in the learning process. In improving the quality of learning, the teacher role and serves as a demonstrator, the class manager, mediator and facilitator, and evaluator. Professional teachers is important because those who have professional skills in various capacities as an educator. Teachers with keprofesionalitasnya it will be able to improve the learning process so as to improve the quality of learning.
\end{abstract}

Keywords: Teacher, Professional, Quality, Learning

\section{PENDAHULUAN}

Profesionalisme menjadi tuntutan dari setiap profesi. Tanpa terkecuali profesi guru yang sehari-hari menangani para anak-anak penerus bangsa dengan berbagai karakteristiknya masing-masing yang tidak sama. Menurut Makawimbang (2011: 134) guru yang profesional adalah mereka yang memiliki kemampuan profesional dengan berbagai kapasitasnya sebagai pendidik. Guru profesional memiliki pengalaman mengajar, kapasitas intelektual, moral, keimanan, ketakwaan, disiplin, tanggung jawab, wawasan kependidikan yang luas, kemampuan manajerial, terampil, kreatif, memiliki keterbukaan profesional dalam memahami potensi, karakteristik dan masalah perkembangan peserta didik, mampu mengembangkan rencana studi dan karir peserta didik serta memiliki kemampuan meneliti dan mengembangkan kurikulum. Namun sekarang ini, dengan berbagai alasan dan latar belakangnya menjadi sangat sibuk sehingga tidak jarang banyak guru yang tidak memahami serta melupakan tugas dan kewajiban pokok mereka sebagai seorang pendidik. Banyak guru enggan meningkatkan kualitas pribadinya dengan kebiasaan membaca untuk memperluas wawasan. Kebiasaan membaca saja sulit, apalagi kebiasaan menulis menjadi hal yang sangat mustahil untuk dilakukan.

Disisi lain, kualitas sumber daya manusia merupakan salah satu aspek penting dalam upaya meningkatkan kualitas kehidupan berbangsa. Negara ini dapat menjadi lebih baik jika masyarakatnya atau sumber daya manusianya berkualitas. Untuk memperoleh sumber daya manusia yang berkualitas, dunia pendidikan mendapat tugas dan kewajiban untuk melakukan proses pendidikan dan pembelajaran untuk sumber daya manusia yang ada, khususnya anak-anak. Anak-anak inilah yang selanjutnya diharapkan dapat menjadi sosok-sosok yang kompeten di bidangnya. 
Untuk mewujudkan tujuan tersebut, berbagai langkah dilakukan oleh dunia pendidikan, terutama terkait dengan sumber daya manusia yang menangani langsung kegiatan pendidikan dan pembelajaran, yaitu guru. Pemerintah telah mencanangkan berbagai program yang bertujuan untuk memberikan kesempatan guru dalam mengembangkan dan meningkatkan kualitas dirinya. Untuk mendukung kebutuhan dana pendidikan, pemerintah mengalokasikan dana untuk pendidikan sampai sebesar 20\% dari APBN. Berbagai program yang telah dicanangkan tersebut setidaknya merupakan langkah konkret yang dicanangkan pemerintah dalam upaya mengangkat kualitas pendidikan. Selama ini, kurangnya kualitas pendidikan disebabkan karena kualitas guru yang belum sesuai dengan tuntutan profesinya. Para guru masih dianggap belum mempunyai kemampuan yang layak untuk menyelenggarakan proses pendidikan dan pembelajaran sehingga perlu secara berkesinambungan dilakukan peningkatan.

\section{PEMBAHASAN}

\subsection{Profesionalisme Guru}

Profesionalisme adalah sebuatan yang mengacu kepada sikap mental dalam bentuk komitmen dari para anggota profesi untuk senantiasa mewujudkan dan meningkatkan kualitas profesionalnya. Sedangkan yang dimaksud dengan profesionalisme guru adalah sebuah pencerminan sikap mental serta komitmenya terhadap perwujudan dan peningkatan kualitas kompetensi keguruannya dengan segala upaya dan strategi dan senantiasa mengembangkan kemampuan dirinya sesuai dengan tuntutan kemajuan zaman, sehingga keberadaannya senantiasa memberikan makna (Rudi, 2014).

Menurut Nurfadilah (2014), guru profesional akan tercermin dalam penampilan pelaksanaan tugas-tugas yang ditandai dengan keahlian baik dalam materi maupun metode. Dengan keahliannya itu, seorang guru mampu menunjukkan otonominya, baik pribadi maupun sebagai pemangku profesinya. Disamping keahliannya itu, sosok guru yang profesional ditunjukkan melalui tanggung jawabnya dalam melaksanakan seluruh pengabdiannya dan tanggung jawabnya sebagai guru kepada peserta didik, orang tua, masyarakat, bangsa negara, dan agamanya. Berikut merupakan sikap-sikap profesionalitas guru (Nurfadilah, 2014):

1) Guru memandang tugas sebagai bagian dari ibadah;

2) Guru memandang profesi guru adalah mulia dan terhormat;

3) Guru menganggap kerja itu adalah amanah;

4) Guru memandang profesi guru sebagai panggilan jiwa;

5) Guru menganggap kerja itu nikmat dan menyenangkan;

6) Guru menganggap kerja itu sebagai bentuk pengabdian;

7) Guru memiliki rasa/ruhul jihad dalam mengajarnya;

8) Guru mempelajari setiap aspek dari tugasnya;

9) Guru akan secara cermat menemukan apa yang diperlukan dan diinginkan;

10) Guru memandang, berbicara, dan berbusana secara sopan dan elegan;

11) Guru akan menjaga lingkungan kerjanya selalu rapi dan teratur;

12) Guru bekerja secara jelas dan terarah;

13) Guru tidak membiarkan terjadi kesalahan;

14) Guru berani terjun kepada tugas-tugas yang sulit;

15) Guru akan mengerjakan tugas secepat mungkin;

16) Guru akan senantiasa terarah dan optimistik;

17) Guru akan memanfaatkan dana secara cermat;

18) Guru bersedia menghadapi masalah orang lain; 
19) Guru menggunakan nada emosional yang lebih tinggi seperti antusias, gembira, penuh minat, bergairah;

20) Guru akan bekerja sehingga sasaran tercapai;

21) Guru menghasilkan sesuatu melebihi dari yang diharapkan;

22) Guru menghasilkan sesuatu produk atau pelayanan bermutu;

23) Guru mempunyai janji untuk masa depan.

Profesionalisme guru memberikan keleluasaan peluang untuk perbaikan dan pengembangan diri yang memungkinkan guru dapat memberikan pelayanan sebaik mungkin dan memaksimalkan kompetensinya. Menurut Rudi (2014), ciri keprofesionalan guru dapat ditunjukan oleh lima sikap, yaitu:

1) Keinginan untuk selalu menampilkan perilaku yang mendekati standar ideal.

2) Meningkatkan dan memelihara citra profesi.

3) Keinginan untuk senantiasa mengejar kesempatan pengembangan professional yang dapat meningkatkan dan memperbaiki kualitas pengetahuan dan keterampilan.

4) Mengejar kualitas dan cita-cita dalam profesi.

5) Memiliki kebanggan terhadap profesinya.

\subsection{Prinsip-Prinsip Profesionalisme Guru}

Berdasarkan Undang-Undang Nomor 14 Tahun 2005 Tentang Guru dan Dosen, profesi guru merupakan bidang pekerjaan khusus yang dilaksanakan berdasarkan prinsip sebagai berikut:

1) Memiliki bakat, minat, panggilan jiwa, dan idealisme;

2) Memiliki komitmen untuk meningkatkan mutu pendidikan, keimanan, ketakwaan, dan akhlak mulia;
3) Memiliki kualifikasi akademik dan latar belakang pendidikan sesuai dengan bidang tugas;

4) Memiliki kompetensi yang diperlukan sesuai dengan bidang tugas;

5) Memiliki tanggungjawab atas pelaksanaan tugas keprofesionalan;

6) Memperoleh penghasilan yang ditentukan sesuai dengan prestasi kerja;

7) Memiliki kesempatan untuk mengembangkan keprofesionalan secara berkelanjutan dengan belajar sepanjang hayat;

8) Memilikijaminan perlindungan hukum dalam melaksanakan tugas keprofesionalan; dan

9) Memiliki organisasi profesi yang mempunyai kewenangan mengatur hal-hal yang berkaitan dengan tugas keprofesionalan guru.

\subsection{Kewajiban Guru Profesional}

Sebagai guru yang profesesional dalam melaksankan tugas keprofesionalan menurut Undang-Undang Nomor 14 Tahun 2005 Tentang Guru dan Dosen, maka guru dituntut memiliki kewajiban yaitu:

1) Merencanakan pembelajaran, melaksanakan proses pembelajaran yang bermutu, serta menilai dan mengevaluasi hasil pembelajaran;

2) Meningkatkan dan mengembangkan kualifikasi akademik dan kompetensi secara berkelanjutan sejalan dengan perkembangan ilmu pengetahuan, teknologi, dan seni;

3) Bertindak objektif dan diskriminatif atas dasar pertimbangan jenis kelamin, agama, suku, ras, dan kondisi fisik tertentu atau latar belakang keluarga dan status sosial ekonomi peserta didik dalam pembelajaran;

4) Menjunjung tinggi peraturan perundang-undangan, hukum dan 
kode etik guru, serta nilai-nilai agama dan etika; dan

5) Memelihara dan memupuk persatuan dan kesatuan bangsa.

\subsection{Kompetensi Guru}

Dalam Undang-undang Republik Indonesia Nomor 14 tahun 2005 Tentang Guru dan Dosen, kompetensi adalah seperangkat pengetahuan, keterampilan, dan perilaku yang harus dimiliki, dihayati, dan dikuasai oleh guru dalam melaksanakan tugas keprofesionalan. Kompetensi yang harus dimiliki oleh guru berdasarkan Undang-Undang Nomor 14 Tahun 2005 tentang Guru dan Dosen, yang menyatakan bahwa Kompetensi guru meliputi kompetensi pedagogik, kompetensi kepribadian, kompetensi sosial, dan kompetensi profesional yang diperoleh melalui pendidikan profesi.

Dalam Peraturan Pemerintah Republik Indonesia Nomor 74 Tahun 2008 Tentang Guru menyatakan:

1) Kompetensi Pedagogik

Kompetensi pedagogik merupakan kemampuan guru dalam pengelolaan pembelajaran peserta didik yang sekurang-kurangnya meliputi:

1. Pemahaman wawasan atau landasan kependidikan;

2. Pemahaman terhadap peserta didik;

3. Pengembangan kurikulum atau silabus;

4. Perancangan pembelajaran;

5. Pelaksanaan pembelajaran yang mendidik dan dialogis;

6. Pemanfaatan teknologi pembelajaran;

7. Evaluasi hasil belajar; dan

8. Pengembangan peserta didik untuk mengaktualisasikan berbagai potensi yang dimilikinya.

2) Kompetensi kepribadian

Kompetensi kepribadian adalah kemampuan kepribadian yang mantap sekurang-kurangnya meliputi:
1. Beriman dan bertakwa;

2. Berakhlak mulia;

3. Arif dan bijaksana;

4. Demokratis;

5. Mantap;

6. Berwibawa;

7. Stabil;

8. Dewasa;

9. Jujur;

10. Sportif;

11. Menjadi teladan bagi peserta didik dan masyarakat;

12. Secara obyektif mengevaluasi kinerja sendiri; dan

13. Mengembangkan diri secara mandiri dan berkelanjutan.

3) Kompetensi Sosial

Kompetensi sosial merupakan kemampuan guru sebagai bagian dari masyarakat yang sekurang-kurangnya meliputi kompetensi untuk:

1. Berkomunikasi lisan, tulis, dan/atau isyarat secara santun;

2. Menggunakan teknologi komunikasi dan informasi secara fungsional;

3. Bergaul secara efektif dengan peserta didik, sesame pendidik, tenaga kependidikan, pimpinan satuan pendidikan, orang tua atau wali peserta didik;

4. Bergaul secara santun dengan masyarakat sekitar dengan mengindahkan norma serta sistem nilai yang berlaku; dan

5. Menerapkan prinsip persaudaraan sejati dan semangat kebersamaan.

4) Kompetensi Profesional

Kompetensi professional merupakan kemampuan guru dalam menguasai pengetahuan bidang ilmu pengetahuan, teknologi, dan/atau seni dan budaya yang diampunya yang sekurang-kurangnya meliputi penguasaan:

1. Materi pelajaran secara luas dan mendalam sesuai dengan standar isi 
program satuan pendidikan, mata pelajaran, dan/atau kelompok mata pelajaran yang akan diampu; dan

2. Konsep dan metode disiplin keilmuan, teknologi, atau seni yang relevan, yang secara konseptual menaungi atau koheren dengan program satuan pendidikan, mata pelajaran, dan/atau kelompok mata pelajaran yang akan diampu.

5) Kompetensi kepemimpinan

Kompetensi kepemimpinan sebagaimana dimaksud pada Peraturan Menteri Agama Nomor 16 Tahun 2010 meliputi:

1. Kemampuan membuat perencanaan pembudayaan pengamalan ajaran agama dan perilaku akhlak mulia pada komunitas sekolah sebagai bagian dari proses pembelajaran agama;

2. Kemampuan mengorganisasikan potensi unsur sekolah secara sistematis untuk mendukung pembudayaan pengamalan ajaran agama pada komunitas sekolah;

3. Kemampuan menjadi inovator, motivator, fasilitator, pembimbing dan konselor dalam pembudayaan pengamalan ajaran agama pada komunitas sekolah; serta

4. Kemampuan menjaga, mengendalikan, dan mengarahkan pembudayaan pengamalan ajaran agama pada komunitas sekolah dan menjaga keharmonisan hubungan antar pemeluk agama dalam bingkai Negara Kesatuan Republik Indonesia.

\subsection{Indikator Pengukuran Profesionalisme Guru}

Profesionalisme guru menurut pendapat para ahli diukur oleh beberapa indikator, antara lain (Makawimbang, 2011: 136-137):

1) Untuk menjadi guru yang profesional, seorang guru dituntut memiliki lima hal, yakni: a) Guru mempunyai komitmen pada siswa dan proses belajarnya. Ini berarti bahwa komitmen tertinggi guru adalah kepentingan siswanya.

b) Guru menguasai secara mendalam bahan/mata pelajaran yang diajarkan serta cara mengajarkannya kepada siswa. Bagi guru, hal ini merupakan dua hal yang tidak dapat dipisahkan.

c) Guru bertanggung jawab memantau hasil belajar siswa melalui berbagai teknik evaluasi, mulai cara pengamatan dalam prilaku siswa sampai tes hasil belajar.

d) Guru mampu berpikir sistematis tentang apa yang dilakukannya dan belajar dari pengalamannya. Artinya harus selalu ada waktu untuk guru guna mengadakan refleksi dan koreksi terhadap apa yang telah dlakukannya. Untuk bisa belajar dari pengalaman, ia harus tahu nama yang benar dan salah, serta baik dan buruk dampaknya pada proses belajar siswa.

e) Guru seyogianya merupakan bagian dari masyarakat belajar dalam lingkungan profesinya, misalnya PGRI dan organisasi profesi lainnya.

2) Ace Suryani dalam Makawimbang (2011: 136) mengungkapkan bahwa guru yang bermutu dapat diukur dengan lima indikator, yaitu:

a) Kemampuan profesional, sebagaimana terukur dari ijazah, jenjang pendidikan, jabatan dan golongan, serta pelatihan.

b) Upaya profesional, sebagaimana terukur dari kegiatan mengajar, pengabdian dan penelitian.

c) Waktu yang dicurahkan untuk kegiatan profesional, sebagaimana terukur dari masa jabatan, pengalaman mengajar serta lainnya. 
d) Kesesuaian antara keahlian dan pekerjaannya, sebagaimana terukur dari mata pelajaran yang diampu, apakah telah sesuai dengan spesialisasinya atau tidak.

e) Tingkat kesejahteraan sebagaimana terukur dari upah, honor atau penghasilan rutinnya. Tingkat kesejahteraan yang rendah bisa mendorong seorang pendidik untuk melakukan kerja sambilan, dan bilamana kerja sambilan ini sukses, bisa jadi profesi mengajarnya berubah menjadi sambilan.

3) Kemampuan profesional guru dapat diwujudkan dengan kompetensi guru yang meliputi:

a) Menguasai bahan, meliputi:

- Menguasai bahan bidang studi dalam kurikulum.

- Menguasai bahan pengayaan/ penunjang bidang studi.

b) Mengelola program belajar-mengajar, meliputi:

- Merumuskan tujuan pembelajaran.

- Mengenal dan menggunakan prosedur pembelajaran yang tepat.

- Melaksanakan program belajarmengajar.

- Mengenal kemampuan anak didik.

c) Mengelola kelas, meliputi:

- Mengatur tata ruang kelas untuk pelajaran

- Menciptakan iklim belajarmengajar yang serasi.

d) Penggunaan media atau sumber, meliputi:

- Mengenal, memilih dan menggunakan media.

- Membuat alat bantuyang sederhana.

- Menggunakan perpustakaan dalam proses belajar-mengajar.
- Menggunakan micro teaching untuk unit program pengenalan lapangan

e) Menguasai landasan-landasan pendidikan.

f) Mengelola interaksi-interaksi belajarmengajar.

g) Menilai prestasi siswa untuk kepentingan pelajaran.

h) Mengenal fungsi layanan bimbingan dan konseling di sekolah, meliputi:

- Mengenal fungsi dan layanan program bimbingan dan konseling,

- Menyelenggarakan layanan bimbingan dan konseling.

i) Mengenal dan menyelenggarakan administrasi sekolah.

j) Memahami prinsip-prinsip dan menafsirkan hasil penelitian pendidikan guna keperluan pengajaran.

\subsection{Konsep Peningkatan Mutu Pembelajaran}

Mutu pembelajaran merupakan bagian dari mutu pendidikan secara keseluruhan. Mutu pendidikan adalah kemampuan sekolah dalam pengelolaan sekolah secara operasional dan efisien terhadap komponen-komponen yang berkaitan dengan sekolah, sehingga menghasilkan nilai tambah terhadap komponen tersebut menurut norma atau standar yang berlaku (Kemendikbud, 2014:7). Dari pengertian itu, maka mutu pembelajaran adalah kemampuan yang dimiliki sekolah dalam menyelenggarakan pembelajarannya secara efektif dan efisien sehingga menghasilkan manfaat yang bernilai tinggi bagi pencapaian tujuan pengajaran yang telah ditentukan.

Sebagaimana yang telah dikemukakan bahwa peningkatan mutu pembelajaran akan terwujud secara baik apabila dalam pelaksanaannya didukung oleh komponenkomponen peningkatan mutu yang ikut andil 
dalam pelaksanannya, antara lain (Rosdijati \& Widyaiswara, 2015):

1) Penampilan Guru. Komponen yang menunjang terhadap peningkatan mutu pembelajaran adalah penampilan guru, artinya bahwa rangkaian kegiatan yang dilakukan seorang guru dalam melaksanakan pengjaran sangat menentukan terhadap mutu pembelajaran yang dihasilkan. Kunci keberhasilannya mengingat bahwa guru yang merupakan salah satu pelaku dan bahkan pemeran utama dalam penyelenggaraan pembelajaran, sehingga diharapkan penampilan gutu harus benar-benar memiliki kemampuan, keterampilan dan sikap yang profesional yang pada akhirnya mampu menunjang terhadap peningkatan mutu pembelajaran yang akan dicapai.

2) Penguasaan Materi/Kurikulum. Komponen lainnya yang menunjang terhadap peningkatan mutu pembelajaran yaitu penguasaan materi/kurikulum. Penguasaan ini sangat mutlak harus dilakukan oleh guru dalam menyelenggarakan pembelajaran, mengingat fungsinya sebagai objek yang akan disampaikan kepada peserta didik. Dengan demikian penguasaan materi merupakan kunci yang menentukan keberhasilan dalam meningkatkan mutu pembelajaran, sehingga seorang guru dituntut atau ditekan untuk menguasai materi/kurikulum sebelum melakukan pengajaran di depan kelas.

3) Penggunaan Metode Mengajar. Penggunaan metode mengajar juga merupakan komponen dalam peningkatan mutu pembelajaran yang menunjukkan bahwa metode mengajar yang akan dipakai guru dalam menerangkan di depan kelas tentunya akan memberikan konstribusi terhadap peningkatan mutu pembelajaran. Dengan menggunakan metode mengajar yang benar dan tepat, maka memungkinkan akan mempermudah siswa memahami materi yang akan disampaikan.

4) Pendayagunaan Alat/Fasilitas Pendidikan. Kemampuan lainnya yang menentukan peningkatan mutu pembelajaran yaitu pendayagunaan alat-fasilitas pendidikan. Mutu pembelajaran akan baik apabila dalam pelaksanaan pembelajaran didukung oleh alat/fasilitas pendidikan yang tersedia. Hal ini akan memudahkan guru dan siswa untuk menyelenggarakan pembelajaran, sehingga diharapkan pendayagunaan alat/fasilitas belajar harus memperoleh perhatian yang baik bagi sekolahsekolah dalam upaya mendukung terhadap peningkatan mutu pembelajaran.

5) Penyelengaraan Pembelajaran dan Evaluasi. Mutu pembelajaran ditentukan oleh penyelenggaraan pembelajaran dan evaluasi yang menunjukkan bahwa pada dasarnya mutu akan dipengaruhi oleh proses. Oleh karena itu guru harus mampu mengelola pelaksanaan dan evaluasi pembelajaran, sehingga mampu mewujudkan peningkatan mutu yang optimal.

6) Pelaksanaan Kegiatan Kurikuler dan Ekstra-kurikuler. Peningkatan mutu pembelajaran dipengaruhi pula oleh pelaksanaan kegiatan kurikuler dan ekstra-kurikuler yang menunjukkan bahwa mutu akan mampu ditingkatkan apabila dalam pembelajaran siswa ditambah dengan adanya kegiatan kurikuler dan esktra-kurikuler. Kegiatan tersebut perlu dilakukan, 
mengingat akan menambah pengetahuan siswa di luar pengjaran inti di kelas dan tentunya hal ini akan menjadi lebih baik terutama dalam meningaktkan kreativitas dan kompenetis siswa.

\subsection{Peran Guru Profesional Dalam Meningkatkan Mutu}

Menurut Surya (2005: 48) guru merupakan komponen penting dalam proses pembelajaran. Dengan keprofesionalitasnya itu guru akan mampu memperbaiki proses pembelajaran, sehingga dapat dengan otomatis pula dapat meningkatkan mutu pendidikan. Sebab guru professional tentunya akan memberikan seluruh kemampuannya untuk kepentingan kemajuan mutu pendidikan itu sendiri. Semakin professional guru, maka semakin dapat memperbaiki proses pembelajaran, dan semakin meningkat kualitas pencapaian tujuan pembelajaran, karena guru memiliki peranan yang besar dalam pembelajaran, yaitu:

1) Sebagai planner: Guru sebagai perencana segala sesuatu sebelum dilaksanakan proses pembelajaran.

2) Sebagai organisator: Guru bertindak sebagai penyelenggara proses edukatif, dituntut mampu mengorganisasikan jalannya proses pembelajaran sebaik-baiknya.

3) Sebagai fasilitator: Gurulah yang member jalan kemudahan dalam memecahkan suatu masalah pelajaran.

Menurut Usman (2004: 6-9) peran dan fungsi guru dalam meningkatkan mutu pembelajaran, meliputi:

1) Guru sebagai demonstrator berfungsi untuk mendemonstrasikan suatu materi pembelajaran, sehingga lebih mudah dimengerti dan dipahami oleh siswa. Oleh karena itu guru harus mampu menguasai bahan atau materi pelajaran yang akan diajarkannya serta senan- tiasa mengembangkan kemampuannya yang pada akhirnya mampu memperagakan apa yang diajarkannya secara didaktis.

2) Guru sebagai pengelola kelas berfungsi untuk mengendalikan dan mengorganisasikan siswa di dalam kelas agar lebih terarah kepada tujuan pembelajaran. Oleh karena itu guru harus mampu mengelola kelas karena kelas merupakan lingkungan belajar serta merupakan suatu aspek dari lingkungan sekolah yang perlu diorganisasikan.

3) Guru sebagai mediator dan fasilitator berfungsi untuk memperagakan suatu media atau alat pembelajaran yang mendukung materi sehingga siswa lebih merasa jelas. Oleh karena itu guru hendaknya memiliki pengetahuan dan pemahaman yang cukup tentang media pendidikan sebagai alat komunikasi guna mengefektifkan pembelajaran.

4) Guru sebagai evaluator berfungsi untuk mengevaluasi hasil belajar siswa. Oleh karena itu guru harus melaksanakan evaluasi pada waktuwaktu tertentu selama satu periode pendidikan untuk mengadakan penilaian terhadap hasil yang telah dicapai, baik oleh pihak terdidik maupun oleh pendidik.

Peranan guru dalam meningkatkan mutu pembelajaran menempati posisi yang penting dalam menentukan keberhasilannya, mengingat guru sebagai figur yang secara langsung terlibat dalam pembelajaran di dalam kelas. Peranan guru dalam meningkatkan mutu pembelajaran dapat diidentifikasi dari perilaku guru sebagai fasilitator, demonstrator, pengelola kelas, mediator dan evaluator. Kelima peran guru tersebut akan dapat mempengaruhi peningkatan mutu pembelajaran, namun tentu diperlukan lagi 
hal yang lebih konkrit agar mutu pembelajaran lebih baik lagi.

\section{SIMPULAN}

Guru merupakan komponen penting dalam proses pembelajaran. Dengan keprofesionalitasnya itu guru akan mampu memperbaiki proses pembelajaran sehingga dapat meningkatkan mutu pendidikan. Sebab guru professional tentunya akan memberikan seluruh kemampuannya untuk kepentingan kemajuan mutu pendidikan itu sendiri. Semakin professional guru, maka semakin dapat memperbaiki proses pembelajaran, dan semakin meningkat kualitas pencapaian tujuan pembelajaran. Dalam meningkatkan mutu pembelajaran, guru berperan dan berfungsi sebagai demonstrator, pengelola kelas, mediator dan fasilitator, serta evaluator. Kelima peran guru tersebut akan dapat mempengaruhi peningkatan mutu pembelajaran, namun tentu diperlukan lagi hal yang lebih konkrit agar mutu pembelajaran lebih baik lagi.

Dalam usahanya meningkatkan mutu pembelajaran, masih terdapat juga permasalahan-permasalahan seperti ada guru yang memiliki kualifikasi pendidikan kurang, sikap profesionalisme guru dalam melaksanakan tugas masih rendah, persiapan guru untuk melaksanakan pengajaran yang kurang mantap, kurangnya memanfaatkan media dan sumber belajar, dan masih rendahnya inovasi serta kreativitas mengajar guru.

\section{DAFTAR PUSTAKA}

Kemendikbud. 2014. Petunjuk Peningkatan Mutu Pendidikan di Sekolah. Jakarta:

Kemendikbud
Makawimbang, Jerry H. 2011. Supervisi dan Peningkatan Mutu Pendidikan. Bandung: Alfabeta

Nurfadhilah, Dina. 2014. Guru Profesional: Upaya Meningkattkan Kualitas Pendidikan. https://dinanurfadhilah. wordpress.com, Diakses pada tanggal 12 Mei 2016

Peraturan Menteri Agama Republik Indonesia Nomor 16 Tahun 2010 Tentang Pengelolaan Pendidikan Agama Pada Sekolah

Peraturan Pemerintah Republik Indonesia Nomor 74 Tahun 2008 Tentang Guru

Rosdijati, Nani dan Widyaiswara. 2015. Peran dan Fungsi Guru Dalam Meningkatkan Mutu Pembelajaran. http:// www.lpmpjateng.go.id, Diakses pada tanggal 14 Mei 2016

Rudi. 2014. Peranan Profesionalisme Guru dalam Upaya Meningkatkan Mutu Pendidikan. http://www.infodiknas.com, Diakses pada tanggal 14 Mei 2016

Surya. H.M. 2008. Kapita Selekta Pendidikan SD. Jakarta: Universitas Terbuka

Undang-Undang Republik Indonesia Nomor 14 Tahun 2005 Tentang Guru dan Dosen

Usman. 2004. Menjadi Guru Profesional. Bandung: Angkasa 